\title{
ЛІНГВОПОЕТИКА
}

\section{ВИДО-ЧАСОВІ ВІДНОШЕННЯ ЯК КОМПОЗИЦІЙНИЙ ЗАСІБ ОРГАНІЗАЦІЇ ЛІРИЧНОГО ТВОРУ}

У статті втілено задум з'ясувати роль послідовності й співвідношення видо-часових форм дієслова для організачіі поетичного тексту, оскільки иі форми моделюють хронотоп, що тежить в основі твору. Доведено, що композиційні можливості видо-часових форм залежать від їхніх типових й оригінальних функцій, з'ясовано поширеність тих чи тих форм у тіричних текстах, їхню кореляцію для вираження авторського задуму та участь у низиі стилістичних прийомів і фігур. Дослідження граматичної, системної згрупованості видо-часових форм уможливлює виявлення мовних засобів організації текстів різного типу, зокрема й поетичних.

Ключові слова: видо-часові форми дієслова, граматична семантика, хронотоп, ретроспективна й проспективна темпоральні композицї̈ твору, стилістичні прийоми.

Oleksenko O. Vyd-Tense Correlation as a Means of the Compositional Organization of Lyrics. The article implements the idea to reveal the role of the sequence and correlation of vyd-tense verbal forms in the organization of a lyric text. The research is topical because it studies vyd-tense ties between verbs of a text in order to interpret it and identify the author's ideas and intentions. The idea is motivated by the fact that vyd-tense verbal forms are the main bearers of textual chronotope features, a means of the reconstruction of life and thought dynamics; these forms have powerful stylistic potential, which has often become the object of linguists' attention. The study concentrates on the wide use of the Present Non-Actual tense in lyrics and on its influence on creating the compositional frame of a text as well as on its active part in forming such stylistic devices as anaphora, epiphora, repetition, refrain, juxtaposition, a frame narrative, etc. The article studies the effect of the use of verbs of opposite vyd forms within the bounds of the same temporal plane. The research presents the semantic load of grammar tense forms that change one another transmitting the dynamics of the lyric plot. In view of this, attention is paid to the retrospective type of temporal composition (from Present to Past or from Past or Present Non-Actual to Historical Present) and the prospective type, which appears during the switchover of present forms (rarely past) and future forms.

The observations presented in the article aim to show that the analysis of the sequence and correlation of vyd-tense verbal forms is important for the interpretation 
of a lyric text because grammar tense forms are the basis of the fictional time of a text, and they mold the image of the time developing in a literary work. The analysis of the grammatical systemic clusters of vyd-tense verbal forms allows revealing the language means of organizing texts of various types, poetic in particular.

Key words: vyd-tense verbal form, grammatical semantics, chronotope, retrospective and prospective temporal composition of a text, stylistic device.

\section{Вступ}

Видо-часові форми дієслова як основного носія хронотопних (часопросторових) ознак творів, як засобу відтворення динаміки життя й динаміки думки здавна привертали увагу лінгвістів. Мовознавці одностайно підтримують думку про потужний стилістичний потенціал форм дієслова. I хоча в кількісному відношенні дієслово посідає друге після іменника місце за своєю поширеністю в художніх текстах (дані, наведені П. Дудиком (Дудик, 2005: 184), свідчать про загальне співвідношення іменник-дієслово в художній мові як 2:1), однак дієслово серед усіх частин мови є стилістично найбагатшою категорією, що зумовлено великим обсягом лексичної семантики дієслова, різнотипністю морфологічних категорій, значень, форм.

Дослідники поетичного ідіостилю окремих персоналій звертали увагу на композиційно-синтаксичну роль часових форм дієслова в структурі художнього твору. Основи теорії й методики аналізу цього явища закладені в роботах О. Потебні, О. Пєшковського, розроблені В. Виноградовим і розвинуті С. Єрмоленко, М. Желєзняк, Г. Золотовою, О. Іванчиковою, Н. Ніколіною, М. Поспєловим, О. Чудаковим, Н. Шумаровою та ін. Дієслівні форми при цьому розглядають у єдності їніх часових і видових значень на засадах аспектуальності, з'ясовують їхні співвідносні функції в організації й розгортанні викладу. Факт видо-часової взаємодії, іiї зв'язок з модальністю висловлення відзначають усі граматисти (О. Бондарко, Т. Булигіна, I. Вихованець, А. Загнітко, Г. Золотова, Є. Курилович, І. Милославський, В. Нікітевич, М. Поспєлов, Л. Размусен, В. Русанівський, О. Смирницький, М. Шелякін та багато інших).

О. Бондарко виділив семантичні ознаки, за якими визначаються й диференціюються видо-часові дієслівні форми (темпоральні ознаки попередності, одночасності, послідовності стосовно граматичного моменту мовлення, аспектуально-темпоральні ознаки локалізації дії в часі й перфектності), розмежовуються - услід 
за О. Пєшковським - загальні й часткові значення форм часу, їхнє пряме й переносне вживання. Учений переконливо довів, що граматична категорія дієслівного часу входить у системі мови в більш широку функціонально-семантичну категорію темпоральності, у якій граматичний центр - дієслівні форми часу - взаємодіють з різноманітними засобами, що становлять їі периферію: лексичні показники часу, конструктивно-синтаксичні, видові, модальні, експресивні значення, елементи контексту (Бондарко, 1967; 2002).

Різноманіттю значень часових форм дієслова присвячено значну кількість лінгвістичних праць, і це переконує в тому, що закономірності внутрішньої організації різних значень і відтінків значень часу достеменно не з'ясовані, як не з'ясовані повною мірою й композиційні можливості, закладені у видо-часові відношення дієслів поетичного тексту. 3 необхідністю з'ясування таких зв'язків, необхідних для інтерпретації ліричного тексту, і пов'язана актуальність нашого дослідження.

Мета роботи - з'ясувати роль послідовності й співвідношення видо-часових форм дієслова для організації поетичного тексту.

Досягнення мети передбачає виконання таких завдань: 1) виявити типову й оригінальну функцію видо-часових форм у поетичному тексті; 2) з'ясувати поширеність тих чи тих форм в аналізованих текстах; 3) окреслити своєрідність цих форм у створенні хронотопу ліричного тексту.

Матеріалом дослідження стала лірика українських поетів другої половини XX - початку XXI ст.

\section{Методи та методики дослідження}

Основні методи дослідження - метод вибірки фактичного матеріалу, спостереження за мовним матеріалом, описовий метод з прийомами інтерпретації, лінгвостилістичний аналіз, аналітикосинтетична обробка матеріалу.

\section{Результати та дискусії}

Досліджуючи роль дієслівних форм часу в побудові композиції творів, виходимо з того, що поетичний синтаксис відрізняється від прозового, зокрема синтаксис лірики, який репрезентує зазвичай писемно-монологічне мовлення. Помічено, що «в художньо-белетристичних стилях найбільшу частотність мають форми минулого часу, 
особливо в прозі. Вони добре передають опис подій, розгортання дії в часі, у певній послідовності, конкретизують динамічну ознаку предметів» (Мацько, Сидоренко \& Мацько, 2003: 58). Однак наративний характер семантики цього часу обмежує його використання в ліриці, якій оповідність мало притаманна (тільки в певних жанрах), натомість ознакою ліричного твору, як відомо, $€$ «відтворення життя шляхом безпосереднього вираження почуттів, думок і переживань автора (або персонажа), громадянських і філософських пошуків» (УРЕ, 1981, т.6: 184). Тому в ліричній поезії поширений теперішній час як такий, що найтісніше пов'язує авторські інтенції з реальним життям. В. Виноградов справедливо зауважив: «Теперішній час сам по собі позбавлений руху. Лише в синтагматиці мовленнєвого процесу, у зміні дієслівних форм у їх рухливій низці теперішній час набуває динамічного значення. Отже, динамічність теперішнього часу - не безпосередня, а композиційно зумовлена, не тематико-морфологічна, а сюжетно-синтаксична» (Виноградов, 1972: 135). Отож розглядати композиційну навантаженість теперішнього часу слід тільки з огляду на синтаксичний час окремого вірша.

Слід зазначити, що теперішній актуальний не притаманний ліриці загалом, бо дія в ліричних жанрах зазвичай не співвідноситься 3 моментом мовлення. Уживаним, особливо під час опису природи, $€$ теперішній розширений узуальний, що характеризує повторювані звичні чи метафоризовані дії й стани. Особливо виразний він у поезіях Л. Костенко, оскільки природа в ії творчості становить частину самого ліричного героя, $є$ його продовженням у Всесвіті, саме через природу поетеса осмислює себе у світі. Зокрема, пори року, як зазначає О. Пахльовська, - «це свій окремий психологічний театр у поезії Ліни Костенко», це «магнетичне поле», яке кличе вірш за віршем» (Пахльовська, 2011:5). Наскрізне вживання теперішнього часу в тотожних значеннях створює композиційний каркас тексту: Вже в стільниках стерні немає меду сония. I дика груша журиться: одна. Лиш клаптики червоного сукония шляхам тишає сіра давнина. Проходить осінь, посмішка землиста. Скляніють очі неба і води. Суху розмову полум'я із листям до ночі сумно слухаютв сади... (Л. Костенко). Тут усі дієслова (навіть дієслова руху й соматичної семантики) мають контекстуально інваріантне значення стану природи. Показовим у цьому сенсі $є$ й поезія I. Драча «Калина», де анафорично вживана форма 
1 особи однини теперішнього часу вибудовує вірш, акцентуючи почуття й відчуття ліричного героя: Спиваю сік густий з терпких морозних грон, Спиваю сік жарких жовтневих розкошей, спиваю шурхотливий падолист, Спиваю золоту оскому осені, Сметану вогняну спиваю й захлинаюсь - Спиваю гіркоту коханих вуст, Спиваю материнський дикий трунок. Хрумтить мій смуток. Цукриться мій смак (I. Драч).

Обрамлює поезію Л. Костенко «Сніги метуть. У вікнах біле марево» кільцева будова з рядків, до складу яких увіходить дієслово в 3 особі множини теперішнього часу метуmь, поєднане з іменником у формі множини сніги зі значенням великих обсягів: перший рядок наведено вище як назву твору, а останній - Метуть сніги. Сніги меmymb, метуть. Уживання чотири рази повтореного дієслова в значенні розширеного теперішнього створює враження безкінечних заметілей як вияву циклічної вічності життя.

Надзвичайно композиційно виразним постає повтор дієслова знати із заперечною часткою не у формі 1-ї особи однини теперішнього постійного часу в поезії I. Драча «Калинова балада»: на дванадцять рядків сім уживань не знаю. Дієслово когнітивної семантики бере на себе функцію активного маркера філософського сприйняття дійсності ліричним героєм, зокрема факту недосконалості людського мислення, відсутності всеохопності людського пізнання. Водночас остання строфа починається з протиставлюваного попередньому твердження: Та знаю: мене колисала калина В краю калиновім тонкими руками, І кров калинова, як пісня єдина, Горить в моїм сериі гіркими зірками (І. Драч), що сприймається як апофеоз поетичного задуму автора - акцентування на свойй причетності до найголовнішого - душі України, символом якої виступає калина.

Так само композиційно навантаженим у поезії І. Драча «Дзвони» $є$ епіфоричне вживання фрази, центром якої виступає насичене алітерацією сполучення «дзвони в передзвони дзвонять» з дієсловом у 3 особі множини теперішнього часу, причому всі події у вірші передаються дієсловами в теперішньому часі. Така епіфора слугує підірунтям для виникнення підтекстових асоціацій про плинність життя, про здійсненність і нездійсненність мрій та жадань.

Слід відзначити композиційну вартість у поезії М. Вінграновського «Не чіпай наші сиві минулі тривоги!» форм теперішнього часу, 
які плавно перетікають з теперішнього неактуального в теперішній історичний, розкриваючи тим самим зв'язок поколінь, оживлюючи картини історії України: Пахне звечора небо осінніми птииями, I повітря стоїть, як зелена ропа. Пахне степ чумаками, волами, мазнииями, І вони вже самі виростають в степах! Це не сниться мені!.. Татарва за горбами! I дружини Русі випливають з дібров і далі Я иарюю в тобі!.. Сподівання химерні, Насторожені думи летять, як туман!.. Булавою збиваючи зорі на стерні, Украӥну порубану зводить Богдан (М. Вінграновський).

У межах одного часу композиційно виразним $є$ вживання дієслів доконаного й недоконаного видів. Передусім це стосується сфери минулого часу, де доконаний вид може виступати виразником перфектного результативного значення, а недоконаний зазвичай транслює аористичне значення дії, тривалої в минулому. Зіставлення в одному тексті спільнокореневих дієслів недоконаного й доконаного виду не тільки передає динаміку подій, а й виступає важливим маркером сюжетної лінії. Прикладом може бути вживана рефреном фраза в «Реквіємі Павлові Тичині» I. Драча «Закочувалось на вечірній круд Тичинине золотооке сонце...» й у кінці поезії «Закотилосв на вечірній круг Тичинине золотооке соние».

Зміна форм часу визначає розвиток ліричного сюжету, «на іï основі розвиваються відношення зі- й протиставлення» (Николина, 2013: 92). Наприклад, у вірші І. Драча «Крізь липовий ескорт» зіставлення історії із сучасністю здійснюється за участі форм теперішнього й минулого часу: I невідь-звідки падають изі сни, Як бджоли падали nід Берестечком (І. Драч). Таку темпоральну композицію Н. Ніколіна називає ретроспективною (Николина, 2013: 112). Привертає увагу ретроспективний тип, коли спочатку вживано дієслово у формі минулого часу з перфектним значенням, а далі картини минулого розгортаються за допомогою теперішнього історичного, який надає ім реальності: Мені приснились ми...Схвильовано і тихо Ми ідемо по губи у Дніпрі, І погляд ваш мені любов'ю диха, Веселі плечі ваші бітим сміхом Мені сміються в легітнім Дніпрі!.. (М. Вінграновський)

Явище, коли до тексту вводиться план майбутнього (текст будується на грунті переходу від форм теперішнього - зрідка минулого - до форм майбутнього), дослідниця називає проспективною темпоральною композицією (Николина, 2013: 113). Такі тексти 
часто мають виразний модальний відтінок можливості або бажання на помежів ї з пророцтвом, наприклад, це демонструє поезія Ліни Костенко «В пустелі сизих вечорів»: В пустелі сизих вечорів, в полях безмежних проти неба о, скільки слів і скільки снів мені наснилося про тебе! Не знаю, хто ти, де живеш, кого милуєш і голубиш. А знаю - ти чекаєш теж, тривожно вгадуєш і любиш. I я прийду в життя твоє. Тебе, незнаного, впізнаю, як син вигнания впізнає прикмети батьківського краю. Я ради иьього ладнажить. Всі інші хай проходять мимо, аби в повторах не згубить одне, своє, неповториме (Л. Костенко). Написана в народнопісенному стилі поема М. Вінграновського «Утоплена» рясніє повторами дієслів у всіх часових формах і значеннях, що додає сюжету динаміки. $Є$ строфи, які складаються виключно з дієслів, i їхнє часове, зокрема проспективне протиставлення слугує маркером психічного стану героїв, наприклад: Левко: Не видивляюся, не тішусь, не радію, не плачу, не бентежусь, не журюсь, Захолодію-позахолодію, Піду-розтануі не повернусь (М. Вінграновський). Як видно, і ретроспективна, і проспективна композиції мають виразну змістову значущість.

У самому зіставленні різних темпоральних планів може полягати сенс тексту, різні часові форми несуть концептуальну інформацію й корелюють з основною темою твору. Саме так розкривається тема палкого кохання в поезії М. Вінграновського «Ще під інеєм човен лежав без весла...»: Я тебе обнімав, говорив, цілував, Цілував, говорив, обнімав - обнімаю, Говорю і цілую - сльозою вже став 3 того боку снігів, цього боку немає... (М. Вінграновський). Цьому ж принципу підвладні рядки Л. Костенко, у яких зіставлення дієслова теперішнього часу із семантикою руху летить з минулим екзистенційного слова було в поєднанні з прислівником учора розкриває ідею минущості життя: Життя коротке і шалене. Летить, як иифри на табло. Учора все було зелене. Учора все іще було (Л. Костенко).

\section{Висновки}

Репрезентовані в статті спостереження покликані показати, що для інтерпретації поетичного тексту важливим є розгляд послідовності й співвідношення видо-часових форм дієслова, оскільки «граматичні форми часу лежать в основі художнього часу тексту й моделюють образ часу, що розвивається у творі» (Николина, 2013: 91). 
Вивчення граматичної, системної згрупованості видо-часових форм дієслова підводить до виявлення мовних засобів організації текстів різного типу, зокрема поетичних.

У цій статті, безумовно, розглянуто далеко не все багатоманіття типів часової організації ліричних творів. Подальша розробка цієї типології й опис різних видів темпоральної композиції становить перспективу досліджень у цій сфері.

\section{ЛITЕРАТУРА}

1. Бондарко А. В., Буланин Л. Л. Русский глагол. Ленинград: Просвещение, 1967. 190 с. 2. Бондарко А. В. Теория значения в системе функциональной грамматики: на материале русского языка. Москва: Языки славянской культуры, 2002. 737 с. 3. Виноградов В. В. Современный русский язык. Грамматическое учение о слове. Москва: Высш. шк., 1972. 601 с. 4. Вінграновський Микола. Цю жінку я люблю. Київ: Дніпро, 1990. 208 с. 5. Драч Іван. Сонце і слово. Київ: Дніпро, 1978. 368 с. 6. Дудик П. С. Стилістика української мови: навч. посіб. Київ: Видавн. центр «Академія», 2005. 368 с. 7. Есперсен О. Философия грамматики. Москва: Наука, 1958. 400 с. 8. Золотова Г. А. Коммуникативные аспекты русского синтаксиса. Москва: Наука, 2003. 368 с. 9. Костенко Ліна. Річка Геракліта. Київ: Либідь, 2011. 331 с. 10. Лотман Ю. М. Анализ поэтического текста. Ленинград: Просвещение, 1972. 272 с. 11. Мацько Л. І., Сидоренко О. М., Мацько О. М. Стилістика української мови: підруч. Київ: Вища шк., 2003. 462 с. 12. Николина Н. А. Темпоральная композиція поэтического текста. Поэтическая граматика: в 2 т. Москва: ООО Изд. центр «Азбуковник», 2013. Т. 2. С. 91-121. 13. Пахльовська О. Невидимі причали. Костенко Ліна. Річка Геракліта. Київ: Либідь, 2011. С. 5-14. 14. Сидорова М. Ю. Грамматика художественного текста. Москва: Наука, 2000. 416 с. 15. Українська радянська енциклопедія: у 12 т. 2-е вид. Київ: Голов. ред. УРЕ, 1981. Т. 6. 552 с.

\section{REFERENCES}

1. Bondarko, A. V. \& Bulanin, L. L. (1967). Russkij glagol [Russian verb]. Leningrad: Prosveshhenie [in Russian]. 2. Bondarko, A. V. (2002). Teoriya znacheniya $v$ sisteme funkcional'noj grammatiki: na materiale russkogo yazyka [Theory of meaning in the system of functional grammar: the case of the Russian language]. Moskva: Yazyki slavyanskoj kul'tury [in Russian]. 3. Vinogradov, V. V. (1972). Sovremennyj russkij yazyk. Grammaticheskoe uchenie o slove [Modern Russian language. Grammar doctrine of the word]. Moskva: Vyssh. shk. [in Russian]. 4. Vinhranovskyi, Mykola. (1990). Tsiu zhinku ya liubliu [I love this woman]. Kyiv: Dnipro [in Ukrainian]. 5. Drach, Ivan. (1978). Sontse $i$ slovo [The sun and the word]. Kyiv: Dnipro [in Ukrainian]. 6. Dudyk, P. S. (2005). Stylistyka ukrainskoi movy [Stylistics of the Ukrainian language]. Kyiv: Vydavn. tsentr "Akademiia» [in Ukrainian]. 7. Espersen, O. (1958). Filosofiya grammatiki [Philosophy of grammar]. Moskva: Nauka [in Russian]. 8. Zolotova, G. A. (2003). Kommunikativnye aspekty russkogo sintaksisa [Communicative aspects of Russian syntax]. Moskva: Nauka [in Russian]. 9. Kostenko, Lina. (2011). Richka Heraklita [Heraclitus' River]. Kyiv: Lybid [in Ukrainian]. 10. Lotman, Yu. M. 
(1972). Analiz poe'ticheskogo teksta [Analysis of a poetic text]. Leningrad: Prosveshhenie [in Russian]. 11. Matsko, L. I., Sydorenko, O. M. \& Matsko, O. M. (2003). Stylistyka ukrainskoi movy [Stylistics of the Ukrainian language]. Kyiv: Vyshcha shkola [in Ukrainian]. 12. Nikolina, N. A. (2013). Temporal'naya kompoziciya poe'ticheskogo teksta [Temporal composition of a poetic text]. Poe'ticheskaya grammatika - Poetic grammar. (Vol. 2), (pp. 91-121). Moskva: OOO Izd. centr «Azbukovnik» [in Russian]. 13. Pakhlovska, O. (2011). Nevydymi prychaly [Invisible berths]. Kostenko Lina. Richka Heraklita - Kostenko Lina. Heraclitus' River, (pp. 5-14). Kyiv: Lybid [in Ukrainian]. 14. Sidorova, M. Yu. (2000). Grammatika xudozhestvennogo teksta [Grammar of fiction]. Moskva: Nauka [in Russian]. 15. Ukrainska radianska entsyklopediia [Ukrainian Soviet Encyclopaedia]. (1981). (2nd ed., rev.). (Vol. 6). Kyiv: Holov. red. URE. Kyiv: Holov. red. URE [in Ukrainian].

Олексенко Олена Андріївна - кандидат філологічних наук, професор, завідувач кафедри української мови, Харківський національний педагогічний університет імені Г. С. Сковороди; вул. Валентинівська, 2, Харків, 61168, Україна.

Tel. +38-097-289-68-46

E-mail: oleksenkoolena@gmail.com

http://orcid.org/0000-0002-6541-8040

Oleksenko Olena - PhD in Philology, Professor, Head of the Ukrainian Language Department, H. S. Skovoroda Kharkiv National Pedagogical University; Valentynivska Str. 2, Kharkiv, 61168, Ukraine.

Надійшла до редакції 10 лютого 2020 року 